\title{
Editorial: Without Foundation
}

Are Wittgenstein and Quine saying the same things? As the blurb would have it, this is the question tackled by a recent collection of essays, edited by Robert L. Arrington and Hans-Johann Glock (Wittgenstein and Quine, Routledge, 1966).

The answer would seem to be 'no', and not just for internal Quinean reasons. That the answer is no can begin to seem puzzling when one reflects that both reject the foundation of a first philosophy, both see indeterminacy at the heart of the language, both reject any substantive notion of analyticity, both adopt forms of holism about belief, and both espouse broadly pragmatic outlooks.

But that all goes to show how little these agreements determine one's philosophical outlook. P. M. S. Hacker has it right when in his contribution to the volume he says that

closer scrutiny, however, reveals the two philosophers to be as proximate, and as distant, as members of the far Right and the far Left in the horseshoe-shaped French National Academyone must travel through the whole spectrum of opinion to reach the one viewpoint from the other.

As Hacker insists, if Quine is right, philosophy is an extension of natural science, and philosophical understanding part of the human endeavour to achieve knowledge of the world; if Wittgenstein is right, philosophy is not a quest for knowledge in this sense, but rather to understand our own thought (including science) and to come to see our place within the world aright.

Maybe disagreements of this sort are all part of the Nietzschean pandemonium of free spirits to be expected when thought of foundation is abandoned. But now that Wittgenstein and Quine have been conjoined, awesome editorial marriages suggest themselves: Russell and Sartre? Carnap and Derrida? Moore and Popper? Frege and Heidegger? 